\title{
EDITORIAL
}

\section{DEZ ANOS DA REVISTA DE SAÚDE PÚBLICA}

Com este volume, a Revista de Saúde Pública (RSP) completa dez anos de publicação regular. Na passagem desse decênio torna-se de todo oportuno registrar, ainda que em forma de sucinto editorial, as metas atingidas no aperfeiçoamento deste periódico.

Em 1967 apresentou-se, como decorrência do desenvolvimento nos modernos meios de divulgação científica, a incumbência de substituir os antigos "Arquivos" desta Faculdade, por publicação que melhor preenchesse os atuais requisitos exigidos em periódico técnico-científico. Isso representava a tarefa, nada fácil em nosso meio, do lançamento de nova Revista. Previam-se obstáculos a serem vencidos na aceitação, consubstanciados em obtenção de matéria a publicar, na indexação dos artigos e, como grande desafio autóctone, na regularidade de sua publicação. Eis que, decorrido esse primeiro decênio, pode-se noticiar, de maneira alvissareira, que essas metas foram satisfatoriamente atingidas.

A periodicidade, inicialmente semestral, passou a trimestral a partir de 1972, em conseqüência do aumento considerável de matéria enviada. Tal aspecto veio traduzir a projeção da RSP no campo da Saúde Pública, tanto no âmbito nacional como no internacional. Muito contribuiu, para tanto, a orientação adotada no julgamento dos manuscritos submetidos à apreciação. A sua seleção, aliada à estabilidade da Comissão de Publicaçóes, constituíram-se em fatores positivos que, em processo contínuo de aprimoramento, tendem a elevar cada vez mais o padrão geral dos artigos publicados.

A passagem para a periodicidade trimestral coincidiu com o aperfeiçoamento da normalização da Revista, concretizado na adoção das "Normas para editoração de periódicos técnicos e científicos" preparadas pelo Grupo de Bibliotecários Biomédicos da Associação Paulista de Bibliotecários. Estas normas foram elaboradas com a finalidade de integrar as publicações técnico-científicas nacionais em sistema de rede mundial de informaçóes. Dentre elas podem-se destacar o "número do artigo" e a inclusão de "unitermos", em português e inglês que acompanham os respectivos resumos. Novas seções foram incluídas, a exemplo das recentes "Nótulas da Literatura Mundial" e "Cartas ao Editor".

O nível de penetração da RSP, na literatura mundial, traduz-se pela sua atual inclusão em 15 bibliografias periódicas. Este atinge, por exemplo, a $100 \%$ no "Index Medicus", a 50\% na "Excerpta Medica" e, também, a quase 100\% naquelas de assuntos mais específicos. Convirá ressaltar que tal nível de indexação não é comum à maioria dos periódicos nacionais.

Ao se apreciar o aspecto panorâmico oferecido pela projeção das revistas técnico-científicas latino-americanas na literatura científica internacional, observa-se quadro pouco animador. A disseminação dos dados na rede bibliográfica mundial é realmente pobre. Em valores globais calcula-se que isso não chegue a $10 \%$ dos trabalhos nelas publicados (Arends, 1975)*. Entre as causas dessa situação po-

* ARENDS, T. - Vinculación de latinoamerica a la literatura cientifica y tecnologica internacional. Medicina, 35:505-12, 1975. 
de-se apontar a má qualidade dos periódicos, a sua proliferação desnecessária, a irregularidade, a ausência de seleção dos artigos, a distribuição e tiragem limitadas, além de fatores de ordem pessoal que as afetam sobremaneira. Como aspecto geral, a "vida média" das revistas técnico-científicas latino-americanas pouco vai além de dois anos. Acresce a isso, a situação inflacionária mundial com aumento constante do custo.

Face a tal situação, a RSP desfruta de posição privilegiada, conquistada ao longo destes dez anos. O seu apreciável grau de indexação, reflete a periodicidade, cada vez mais apurada na pontualidade, e o caráter selecionado da matéria publicada. A orientação uniformemente seguida pela sua Comissão de Publicações, deve-se boa parte desse sucesso. Não haverá como negá-lo, as evidências assim o mostram ao se iniciar o segundo decênio que, sem dúvida alguma, levará a RSP a destinos ainda mais elevados.

Oswaldo Paulo Forattini 